\title{
When doing good pays : A first research into the remuneration practices of non-profit executives (particularly the IT sector).
}

\author{
Camille Akmut
}

\begin{abstract}
Research into the compensation of executives of non-profit organizations (with particular attention paid to the technology sector). Collected data is presented in original form, with some analysis of the differentiated remuneration strategies.
\end{abstract}




\section{Introduction}

We concentrate on the IT sector that we are mostly familiar with, but also include data for other select areas (human rights, environmental causes, reproductive health, mainly, these being established domains within the world of charities, and which constitute some of the oldest organizations in this sector e.g. Red Cross, Greenpeace, etc.).

Data is based on information available and found on Charity Navigator.

\section{Data}

$\begin{array}{llll}\text { Compensation } & \% \text { of } & \text { Paid to } & \text { Organization } \\ & \text { Expenses } & \\ \$ 785,000 & 2.09 \% & \text { Salman Khan } & \text { Khan Academy } \\ \$ 772,284 & 0.06 \% & \text { Richard C. Shadyac Jr . } & \text { St. Jude Children's Hospital } \\ \$ 756,312 & 0.30 \% & \text { Carter S. Roberts } & \text { WWF } \\ \$ 673,735 & 0.02 \% & \text { Gail J. McGovern } & \text { American Red Cross } \\ \$ 569,378 & 0.11 \% & \text { Caryl M. Stern } & \text { UNICEF USA } \\ \$ 527,767 & 0.74 \% & \text { Kenneth Roth } & \text { Human Rights Watch } \\ \$ 444,669 & 0.04 \% & \text { Thomas E. Tighe } & \text { Direct Relief } \\ \text { c. } \$ 400,000 & \text { U.S. President } & \\ \$ 343,213 & 0.56 \% & \text { Susan Dunlap } & \text { Planned Parenthood Los Angeles } \\ \$ 307,141 & 0.44 \% & \text { Katherine Maher } & \text { Wikimedia Foundation } \\ \$ 300,000 & 8.89 \% & \text { Rachel B. Tiven } & \text { Lambda Legal } \\ \$ 250,000 & 2.19 \% & \text { Cindy Cohn } & \text { Electronic Frontier Foundation } \\ \text { c. } \$ 250,000 & \text { German } & \text { Chancellor } & \text { Amnesty International USA } \\ \$ 249,227 & 0.63 \% & \text { Margaret Huang } & \text { Mozilla Foundation } \\ \$ 235,829 & 0.97 \% & \text { Mark Surman } & \text { EPIC } \\ \$ 223,129 & 15.35 \% & \text { Marc Rotenberg } & \text { Creative Commons } \\ \$ 214,077 * & - & \text { Ryan Merkley } & \text { Doctors Without Borders, USA } \\ \$ 201,968 & 0.04 \% & \text { Jason Cone } & \text { Oxfam America } \\ \$ 195,952 & 0.21 \% & \text { Maxman Abby } & \text { Books For Africa } \\ \$ 133,262 & 0.36 \% & \text { Patrick Plonski } & \text { Nat. Center for Trans Equality } \\ \$ 128,460 & 7.86 \% & \text { Mara Keisling } & \text { Planned Parenthood of NYC } \\ \$ 108,053 & 0.20 \% & \text { Laura McQuade } & \text { Transgender Law Center } \\ \$ 100,600 & 3.01 \% & \text { Kris Hayashi } & \text { Greenpeace Fund } \\ \$ 100,421 & 0.52 \% & \text { Anne Marie Leonard } & \text { Free Software Foundation } \\ \$ 90,785 & 7.36 \% & \text { John Sullivan } & \end{array}$




\section{Analysis}

We also provide the salary of other professions and people for reference (as far as is publicly known, and known to us).

A median income for "executive directors", "presidents", or "CEO'S" ${ }^{1}$ of non-profits was about 250,000 dollars in our data set.

One organization in particular is a complete outlier where their remuneration practices are concerned : nearly 800.000 dollars were paid to Salman Khan of Khan Academy.

\footnotetext{
${ }^{1}$ This covers the variety of titles attributed to these various individuals.
} 


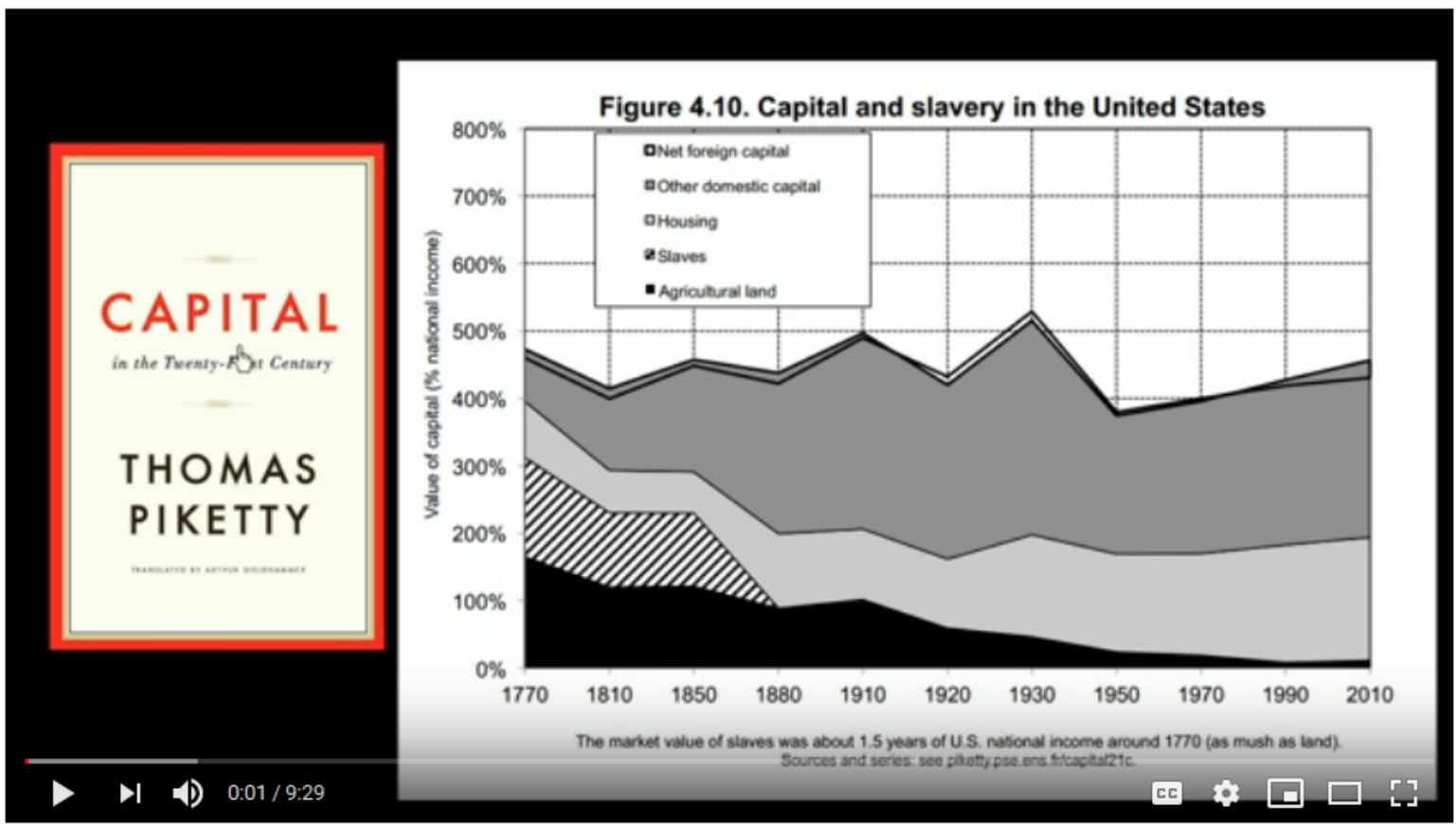

\#YouCanLearnAnything

What is capital? | GDP: Measuring national income | Macroeconomics | Khan Academy

\section{2,871 views}

It 235 I 11 I SHARE $\equiv+$ SAVE $\cdots$

Khan Academy $\odot$

Published on May 26, 2015

Figure 1: Mr. Khan explains Piketty's terminology and, later, capital equation (in abstracto).

A good education is not a series of citations or equations, or well-meant ideals, that can be paraded given various useful occasions. It is there so we can draw real-life lessons from it.

But, the problem with a good education is also that upon encountering millionaire-style salaries paid out to non-profit CEO's (a combination of seemingly contradictory terms which itself ought to leave one wondering), one simply cannot move on with the belief that this is simply "the fashion and style in practice, or in vogue, in certain circles of San Francisco".

Even an established, large charity such as Human Rights Watch that 
practices high salaries - half a million dollars - did not come close to this level of remuneration.

Mr. Khan's salary was equivalent to twice that paid to the President of his country, more than three times that of the leader of a major European country, or, yet, 40 times that of a doctor working for Doctors Without Borders following a decade long training. In fact Mr. Khan's remuneration is higher than that of the U.S. President and German Chancellor combined - a combination of facts which no matter how important, and important it is, the work realized cannot be said to be commensurate.

One justification may be that, such salaries need to be competitive with the rest of the IT sector. But, many if not a majority of the non-profits we have researched belong to that sector and limit their remunerations to 3 times less than practiced by that specific non-profit.

A similar, and related justification will be that, in general, high salaries are a condition to attract good talent. But, for once, much of remuneration practices in the academic world are a contradiction of that. In fact, the exact opposite may be argued : that offering, not low, but reasonable salaries (i.e. in line with most of the rest of society) is a condition to attract the right individuals, those who do place greater value into the values of the organization they serve rather than the number of zeroes accompanying their salary. This would for instance be the case of doctors working for various charities doing work worldwide for almost or minimum wage (e.g. Doctors Without Borders).

In other ways, as the economist John Galbraith noted, there are always justifications for greed $^{2}$.

That other models - including in the IT sector - are possible is demonstrated by the FSF's practices for example : their executive director has a listed salary of 90.000 dollars.

Similar salaries are practiced by both well and lesser-well established charities such as Greenpeace ${ }^{3}$ or PETA, and various non-profits dedicated to the advancement of transgender rights, or the spread of literacy in countries such as Africa through donations of selected books.

Another foundation stood out, the Electronic Privacy Information Center, as being an outlier in terms of the ratio of remuneration and expenses at over $15 \%$ of total expenses redirected to one single person, Marc Rotenberg, its president.

Several foundations active within the IT sector made it so that their executives should receive remuneration equivalent to or higher than that of a leader of a major European country : this includes the Electronic Frontier Foundation, the Wikimedia Foundation, and the aforementioned Khan Academy.

Compensation could not be attributed - or otherwise justified by - the size of the organization, or their relationship to expenses : both the lowest salary uncovered, and the lowest ratio to expenses uncovered, comes from PETA, one of the most visible charities $(20000 \$)$.

\footnotetext{
${ }^{2}$ This includes the peculiar philosophy known as "effective altruism", which we will handle in a separate article entitled "The perfect philosophy for the perfect generation."

${ }^{3}$ Though we only had access to statistics regarding the Greenpeace Fund specifically.
} 
In fact, one other model consisted in one president for a "10 Most Followed Charities" (according to classifications by Charity Navigator) not receiving any compensation $^{4}$ - a model that will be certainly source of much pondering and wondering to these San Francisco-cultured executives.

During the course of our research we also uncovered great disparities within the same organizations or their affiliates : the CEO of Planned Parenthood Los Angeles was remunerated more than 3 times the amount of their counterpart in New York, with no good explanation for differences (as they are both located in comparable, major cities within the same country).

Lastly, many charities we were not able to include in our analysis as for them IRS forms were missing (e.g. "Has not yet filed 7+ years of Form 990's"), which presumably is what Charity Navigator uses to establish their statistics among other things possibly.

\section{Conclusion}

We are uncertain what uses these statistics may have, and fear the negative ones they may (be made to) have. It represents, if anything, a first trial of a longer, and far more reaching research into the compensation of executives in the non-profit sector (extended to many more areas than done here).

It may also help those who practice charitable donations make a donation in the future, here, specifically, based on the criteria of the salary of their executives.

Such a research carries an element of complication in the sense that many of these charitable organizations often embody great ideals, and in fact do great acts - but some of them may wish to look at their own practices first, and specifically from the point of view of economic inequality i.e. the widening gap between the poorest and richest in our contemporary societies. This is not the only point of view to be adopted however, as demonstrated by the recent report on bullying in the workplace at Amnesty International, a charity defending human rights - everywhere but at home.

In Capital in the Twenty-First Century, Piketty writes : "I have no wish to exaggerate the role of technology in the history of ideas, the purely technical issues are worth a moments reflection.". We will turn to these "technical issues" again, and again, in future works. This represents the first in a series of "bitesized" research projects ${ }^{5}$ - this is to say short research papers with almost raw-like data and only the minimal necessary commentary apparatus - meant to inspire other researchers to look into these, once more, not only "technical issues".

\footnotetext{
${ }^{4}$ DAV. "Donors Tracking This Charity" : 10,425.

${ }^{5}$ Of never more than 5 to 10 pages. Never to be done over more than just a few days.
} 
For, these same "technical issues", are the predominant issues of our times. This can be said with no doubt - no other transformation has affected us and affects us as much as they do, and are likely to continue to determine our future as much as them.

When Piketty says "inherited wealth comes close to being as decisive at the beginning of the twenty-first century as it was in the age of Balzacs Pere Goriot.", he once again - for fear of overestimating - underestimates the role of technology, and specifically the role of computer technology. And, to convince himself of that, he only needs to have a short look at any contemporary Billionaires list, such as that compiled by Forbes for instance: Bill Gates (\#2) (Microsoft), Larry Ellison (\#7) (Oracle), Mark Zuckerberg (\#8) (Facebook), Larry Page (\#10) (Google), Sergey Brin (\#14) (Google), Steve Balmer (\#19) (Microsoft), Ma Huateng (\#20) (Tencent), Jack Ma (\#21) (Alibaba), Michael Dell (\#25) (Dell), and on, and on, and on ${ }^{6}$.

Bill Gates, and even the Forbes listing, are mentioned, but all of Zuckerberg, Page, Brin, Balmer and Ma are absent - a fact that ought perhaps to move him to reconsider some of his assumptions, and practices. Bill Gates is contrasted to Bettencourt (\#15) (L'Oreal), the empress of cosmetics, who, as he notes, "never worked a day in her life", but where are the developments on all the others, and the contrasted development of their fortunes? Most of the aforementioned Western tech billionaires come from middle- to upper-class backgrounds, but, their later riches, stupendous by any standards, and nothing to be found in any of Balzac's 19th century portraits, are incommensurate to their beginnings. Specifically, he may wish to turn to the - incongruent - cases of Jack Ma, and the rest of the Communist China tech billionaires. What is Baidu? Who is Robin Li? What kind of social background does Robin Li come from? We just won't know reading Piketty's book, because rather than opening a computer science book, and extend the domain of what social scientists can be and ought to be dealing with and learning, he'd rather reach back to the Pere Goriot, and give us a taste of the old "general knowledge". And, because many like him would rather read Marx, rather than acquiring the required knowledge to talk about technology, but with the Capital held in the other hand (that of Marx to be clear), we'll continue to hear about the Bettencourt's of this world, but not the rest, for some time still. But, not for long.

\section{Bibliography}

Charity Navigator. https://www. charitynavigator.org/.

Piketty, Thomas. 2017. Capital in the Twenty-First Century. Belknap Press.

KonTerra (Wellbeing) Report. 2019. https://www . amnesty.org/en/documents/ org60/9763/2019/en/

\footnotetext{
${ }^{6}$ In other words, one third of our world's current top 25 billionaires can be attributed to computer or related technologies.
} 
Description : in which one learns about the feelings of non- "wellbeing" that comes with working at a human-rights focused charity.

ProPublica. "Nonprofit Explorer". https://projects.propublica.org/nonprofits/

Description : an antecedant to this research.

Khan, Salman. 2015. "What is capital? - GDP: Measuring national income - Macroeconomics - Khan Academy". 26/05. https://www.youtube.com/ watch?v=-epr81PIZYE.

Description : in which one learns (about) the great ability to seperate education from practices.

Forbes. 2019. Billionaires. https://www.forbes.com/billionaires/.

Description : in which one discovers the role and importance of "technological issues" in creating wealth. 


\section{Appendix}

\section{Full table}

*Appears as "Chief Executive Officer".

**Compensation from Affiliates.

***Not compensated.

****People for the Ethical Treatment of Animals.

$* * * * *$ World Wildlife Fund.

******DAV (Disabled American Veterans) Charitable Service Trust. 


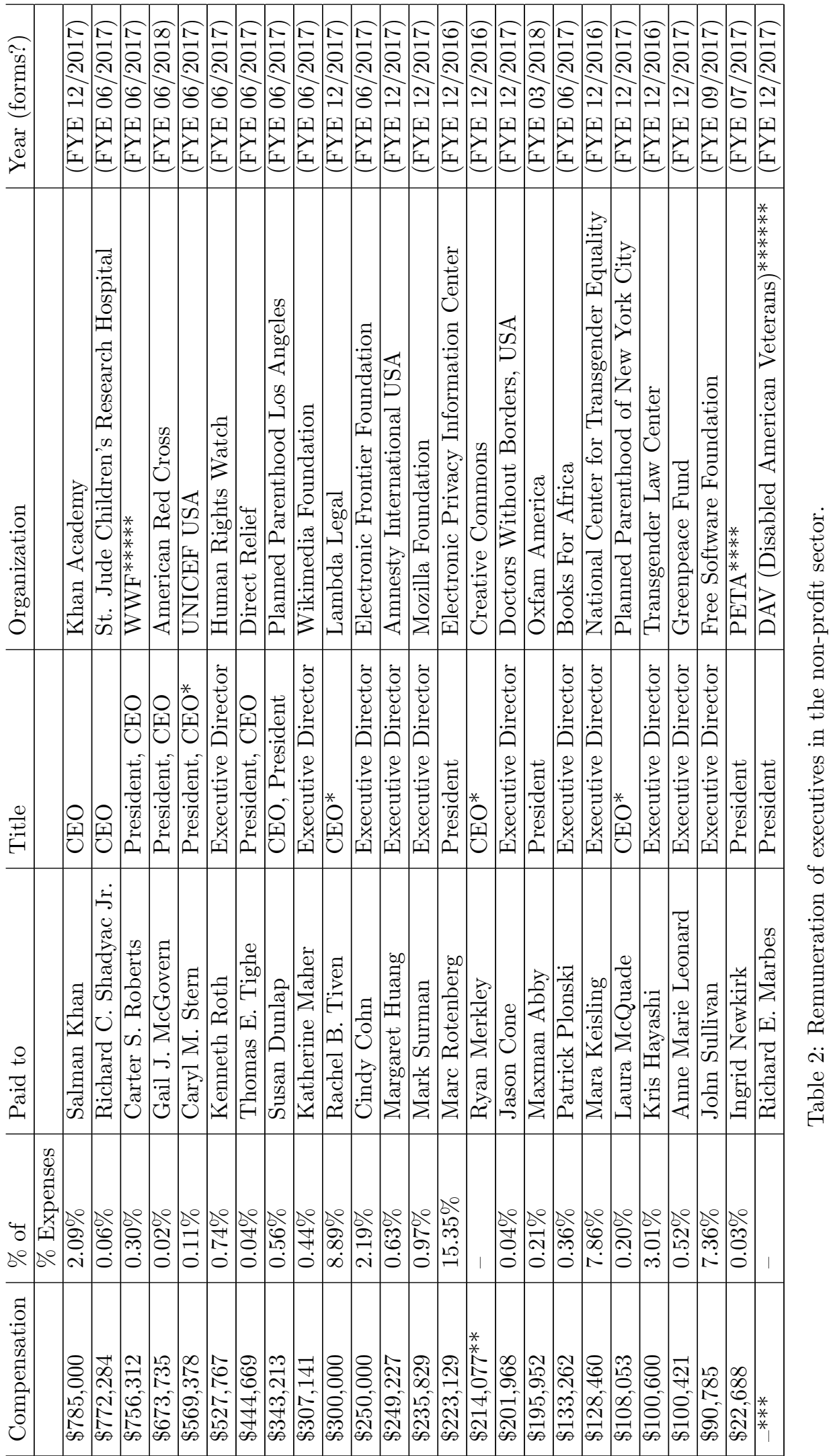

